
\title{
What Is the Brand Macron Standing for?
}

\author{
Bernard Barthalay
}

Looking at the current controversy about the ideological labels to be sticked on the new French President, the answer cannot be but a mixed one. Is he a neoliberal? Is he a Nordic social democrat? Or both? "En même temps" (all of that together), according to his by now famous stock phrase. Which does not mean the question is irrelevant, but that the answer depends on "something completely different", as Monty Python used to say. And, in the eyes of many people, that "something" is his cosmopolitanism.

Judging him from his short record, we are led to consider the composition of the just appointed government. Here again, the most outstanding feature is not that this government is meant to balance out men and women, or the Left and the Right components (with a delicate balance). It is that the most "sovereign" ministries rest in the hands of fluent polyglots, who did not study Germany or other neighboring countries from lectures at the ENA (Ecole Nationale d' Administration), but from living out there. A dream of the French aristocratie d'Etat in the 1950s was a French Europe, a continent governed in the French way, as an antidote to a German Europe, the one that had been defeated.

What is at stake now is the Europeanization of France, with a European Germany in return. It is the cosmopolitanization of both countries, and their partners, to get out of the tragedy that has been going on in the Eurozone since 2000. In Berlin that year, the German Foreign Minister, Joschka Fischer, addressed a select audience at the Humboldt University and declared that Germany was available for a federation. Fischer thought it was overdue. Monnet and Schuman had made a similar invitation, that of a Defence (and Political) Community, which was accepted by Adenauer, but turned down by the French themselves in 1954. Once again in 2000, the French ignored, and the Chirac-Jospin-Védrine troika declined, the German proposal. That rebuff caused resentment among Europhile Germans, which was concealed from the French public but soon backfired. At the first meeting of the European Council in Nice, Schröder demanded a departure from the Monnet-cherished unwritten rule of formal equality between Germany's and France's voting rights in the Council, but that was dismissed. However, the Chancellor made it clear that Germany, from then on, would pursue its own national interest. A new German Germany was born, which resulted in a new Europe of (so-called sovereign) nation states

\section{Taxation is key}

From an economic point of view, Fischer's address was amply justified. A single currency cannot hold without a common budget, common own resources, a common representation, a common Treasury. It is not an issue to be dealt with adopting a positivist approach of whether the currency area is optimal or not, but it is a matter of sovereignty. A single currency area is unsustainable without automatic stabilizers, through a taxand-spend power.

To reach such an institutional configuration, governments that are looking for their own interests through the common interest, according to Monnet's words, are required, not governments bent on their constituents' selves, with only their own re-election in mind. 
Sadly enough, Schröder, the German Social Democrat turned Neoliberal in the wake of the Clinton-Blair Third Way, unilaterally decided an internal devaluation, by cutting wages through a corporatist industrial agreement (Hartz IV), aimed at saving German jobs, thereby pitting European peoples one against the other, in a fierce social competition. This broke the philosophy of the Rome Treaty: the ban of state aids was meant to prevent governments from granting domestic firms a privilege over foreign ones. Hartz IV was the start signal of a race to the bottom that led to a rise in precariousness, poverty and inequality. The unfair competitive advantage triggered a huge permanent trade surplus, labeled Neomercantilism by critical German economists. Schröder lost, but did not stop the dismantling of the common competition policy: he established with Russian oligarchs an illegal German monopoly on the distribution of Russian gas in Central and Western Europe, which the European Commission has long tolerated, and is now trying to fight.

By then, Berlin had another priority: how to manage the growing heap of cash on which Germany is sitting to the benefit of pensioners in an ageing and low-fertility population. This was Schäuble's job: switching Europe from the original social market economy to a market society where fiscal interventions are limited by arbitrary intangible rules, the only ones that a medley of 19 states, with different macroeconomic profiles, could ever agree on. The Chief Accountant Schäuble, obsessed by the pursuit of a zero-deficit (Schwarz-Null), is leading Europe to competitive deflation. The European monetary union was launched in an age of rising wages and prices, to preserve the unity of the common, then single, market, and anchored the fight against inflation on an exchange rate stabilization mechanism, the so-called EMS, first around a basket of currencies, then around the DM itself, the most stable and strongest of all. At a time of capital controls, exchange rate realignments occurred occasionally, hardly ever since disinflation prevailed. At the price of growing unemployment.

With hindsight, competitive disinflation between EEC member states can be seen as a civilized substitute to the fateful interwar competitive devaluations.

In the Schröder-Schäuble era, under competitive deflation, Europeans still have to pay the same price: the loss of jobs and the drop of purchasing power. Competitive deflation is now gradually depriving the euro of its very raison d'etre: the unity of the single market.

Macron, when he speaks of a lost generation of permanent job-seekers, and of almost twenty years lost since the inception of the single currency, and soon ten years since start of the financial crisis, is aware of the additional price that debtors had to pay to creditors in the Eurozone for the sake of the over powerful recovery of Germany, and of Europe's unequal prosperity since the German unification shock. He is intent on moving towards a fiscal union. But he already bumped into Schäuble's stubbornness. The German Minister is no more open now for a Treaty revision than ever before and, above all, he remains hostile to any idea of a common tax-and-spend power under the oversight of a common authority and representation.

Macron will either be helped by German internal political developments and will succeed in convincing both his own government and the next German government to follow him back towards the founders' initial design, or he will have, whatever the success or failure of his planned so-called "reforms", to respond to Berlin by reproducing their onesided approach, but on his own ground, to their great surprise and embarrassment.

Berlin is known to be waiting for French "reforms" of the labour market and cuts in 


\section{Borderless Debate: How to Advance towards a Closer European Union}

taxes and social expenses, which Macron cannot deliver to the desired extent without losing popular support and governmental cohesion. Macron should catch them off- guard, albeit unexpectedly, by doing two things: decentralizing the French Republic massively, giving a far greater autonomy to local and regional governing bodies; reforming the French tax system radically, switching taxation from income to idle assets, bringing it closer to the Swiss or Dutch systems, which would give France two huge competitive advantages.

Macron doesn't back away from the word "Révolution", which was the title of his campaign book. Will he back away from the only two deep reforms all presidential candidates promised in their electoral platforms, but never delivered - the two reforms that are deemed impossible in a Jacobinic and elitist republic? The key to success might be there.

It can take twice as much democracy to complete the euro

From a political point of view, the Europeanization of France requires a very special political strategy which Macron seems to perceive almost instinctively, even if he might not have theorized on it. At least not yet. On the contrary, one of his leftist contenders, the Socialist Hamon, introduced the idea of "un arc progressiste". If Europe is getting closer to a founding moment, it should not federate states only, but citizens, at least what is usually referred to as a "constitutional" majority.

Over time, $60-70 \%$ of the French people used to answer "yes" when asked whether sovereign matters such as the currency, foreign policy, defence and security, should be relinquished to a European system of government. Macron's majority falls, after the first pro-European campaign ever in French politics, within that range.

It is to be recalled that the so-called
Constitutional Treaty, rejected by a 55\% majority in the 2005 French referendum, combined two major flaws, which were highlighted by recent crises: it left the euro without a common tax-and-spend power, and it left foreign affairs, the military and intelligence in the hands of member states. Governments and parties, fearing the populist backfire, agreed to think the Dutch and French "no" was a rejection of any Europe, not a demand for "a more perfect Union".

Macron is betting the other way round: Europeans want a European democracy, no less democratic than member states - a Europe that is a power among world powers, not only a market, however wealthy.

Macron's En Marche movement could be seen as a potential "arc constitutionnel" (constitutional bow, or even rainbow, by reference to Mandela), as it includes former Socialists (PS) as well as former Républicains (LR), and is open to all shades of democratic free thinking, from left to right. Parliamentary elections, whether they result in an En Marche absolute majority or a German-style "Grand Coalition", will encompass such a large spectrum, which is also required all over Europe by any future truly cosmopolitical constitutional moment.

Are there any historical precedents in France? The last two French constitutional moments are instances of such broad trans-partisan foundational alliances. The Fourth Republic (1946) resulted from an alliance between Christian Democrats (MRP), Communists and Socialists. The Constitution of the Fifth Republic (1958), in the context of the Cold War and a post-colonial war in Algeria, was supported by Socialists, Radical democrats, Christian Democrats (MRP), Gaullists and conservative Independents (CNIP).

To the contrary, the two European quasiconstitutional moments in France divided both the Right and the Left: in 1954, the Defence Community fell victim to a now 
obsolete debate between Atlanticists and a ragtag cast of Soviet-aligned and non-aligned MPs; in 2005, opponents to the so-called Constitutional Treaty included people from both the Left and the Right, who confused the single currency with neoliberalism, but rightly anticipated the detrimental effects of an incomplete euro on growth and employment on the one side, and people who, "en même temps" or not, criticized the EU's secretive, remote, unbalanced and unaccountable institutional framework.

While the 1954 line-up is to be forgotten, 2005 is the matrix of the 2017 new, widely transpartisan (or even no-party) configuration of French politics: the Frexit stance on the extreme right, the "Plan B" strategy of the "Insoumis" movement, and the demand by the more or less radical Left wing (Hamon's Socialists, the "Insoumis" and the Communists) for a democratization of the Eurozone, are all representative of real European issues to be tackled without delay. This is needed to form a larger alliance able to reconcile more segments of the French population with Macron's refoundational approach to Europe.

The Right-Left divide of French politics is inadequate to address the European dilemma of unity vs. division. The ideological (and methodological, according to the late Ulrich Beck) gap between the national and the cosmopolitical states of mind are resulting in anachronistic conflicts: they can only be solved through a deeper and fairer democratic debate about the market, the currency and democracy, along the line consistently exemplified by the French economist Michel Aglietta in his most recent works. "The Dual Democracy" (La Double Démocratie), both national and European, is the title of his last book, co-authored with Nicolas Leron. It fits in with Macron's emphasis on both a budget and a representation of the Eurozone, if ever the new President is to keep his campaign promise. Piketty's draft "Treaty for the
Democratization of the Eurozone governance", supported by Hamon, is pointing in the same direction.

\section{Liberty and equality}

From an ethical point of view, Macron lays claim to the legacy of the French philosopher Paul Ricœur. A cursory review of Macron's statements or his book Révolution could leave the reader with the false idea, largely spread by the media, that his political thinking can be summed up easily by a simple formula, just bringing him close to Obama's shade of the Rawlsian egalitarian liberalism. But it would be wrong to stop there. Macron's majority is unusual: De Gaulle 1958, 78,5\%; De Gaulle 1965, 55,2\%; Pompidou 1969, 58,2\%; Giscard 1974, 50,8\%; Mitterrand 1981, 51,8\%; Mitterrand 1988, 54,02\%; Chirac 1995, 52,6\%; Chirac 2002, 82,21\%; Sarkozy 2007, 53,6\%; Hollande 2012, 51,63\%; Macron 2017, 66,1\%. The French people gave more than $60 \%$ of their votes in only three circumstances, when they rejected the past (the Fourth Republic and its political-parties predominance) or a return to the past, be it the abominable description of gas chambers by Le Pen, the father, as a "détail de l'histoire" (a detail of history), or the Maurrasian tradition of "integral nationalism" still embodied by Le Pen, the daughter, and her clique.

Notwithstanding quite legitimate explanations of Le Pen's record (33,9\%) based on the depleted state of some French "forgotten" regions and cities, Macron's victory does not result from a full and unreserved support of his still blurry European project, but from a firm attachment to both the euro and the freedom of movement within the EU. And a strong "plus jamais ça", never ever again both revisionism and a withdrawal into isolation.

Cosmopolitanism, and by the way any Europeanization of our old nations, begins where the acknowledgment of the Other 


\section{Borderless Debate: How to Advance towards a Closer European Union}

prevails over the essentialist, identity-driven perversion of history and law. Macron's cosmopolitism is no exception, and prevailed over hate mongering. But there is more to Ricœur's legacy than an integration of identity and otherness, a premise, if any, of Europe, in the depths of it. There is Beck's already mentioned cosmopolitical principle of additive inclusion as well, Macron's recurrent "en même temps" sounding as an echo of the complexity school and Edgar Morin's dialogues, the consideration of the necessary and complementary presence of antagonistic processes or demands, which in turn is the very meaning of Europe.

Thinking "en même temps" of liberalism and socialism is not new: it happens in times where democrats and progressives are facing forces of tradition and reaction, when the Enlightenment is confronted with the Anti-Enlightenment, whether religious or nationalist. It happened in the French Conseil National de la Résistance. It happened long before among Italian antifascists who even coined liberalsocialismo in one single word. This political dialogue came back more recently with Etienne Balibar's concept of égaliberté.

«Et lanation et l'Europe», since cosmopolitanism requires both, a Europeanized France and a denationalized Europe; "et la liberté et l'égalité», since wealth doesn't trickle down by virtue of the market only.

At a time when French skepticism is growing in this country - and national skepticism in Europe at large - and the self-regulation of markets is legitimately questioned, will Macron be up to the task? It depends on his sticking to additive inclusion. 